\title{
COMMUNICATING KNOWLEDGE TO NEW AUDIENCES: VICTORIAN POPULARIZERS OF SCIENCE ${ }^{1}$
}

\author{
BERNARD LIGHTMAN*
}

York University

\begin{abstract}
In the past historians have tended to explain the existence of a cult of science from about 1850 to 1890 as the result of the work of elite scientists such as Darwin, Huxley, and Tyndall. But this explanation leaves out two crucial factors: the role of popularizers who were not practitioners of science and the occurrence of a communications revolution in the second quarter of the 1800s that established the conditions necessary for what happened in the second half of that century. Once these factors are added to our account of the cult of science, a very different picture emerges, one that forces us to reconsider the standard story of the dominance of the scientific scene by figures like Darwin, Huxley, and Tyndall.
\end{abstract}

Just before Christmas Day, 1862, John Henry Pepper invited a small group of literary and scientific friends, and members of the press, to his Royal Polytechnic Institution on Regent Street in London, England, to see a performance of a play. His plan to surprise his visitors with a preview of a new optical illusion worked better than he could possibly have imagined. The audience was so startled by the ghost illusion that Pepper took out a provisional patent the following day, sensing its almost unlimited potential (Figure 1). When he started showing the ghost illusion at the Polytechnic, a periodical described it as a "real veritable spectre, so real that the spectator hardly believes the Professor when he states that it is a mere illusion, a fact, however, which he establishes by walking clean through it" (University of Westminster Archives). Pepper's ghost caused a sensation and drew thousands of visitors to the Royal Polytechnic Institution.

Pepper wasn't the only lecturer on science who attracted the attention of Victorian audiences in 1862. On November 10th, Thomas Henry Huxley delivered the first of six weekly lectures to an audience

\footnotetext{
Author to whom correspondence should be address: lightman@yorku.ca.

1 This paper is based on an invited lecture given on May 7th, 2012, at the University of King's College, Halifax, NS, on the occasion of the 150th anniversary of the NSIS.
} 


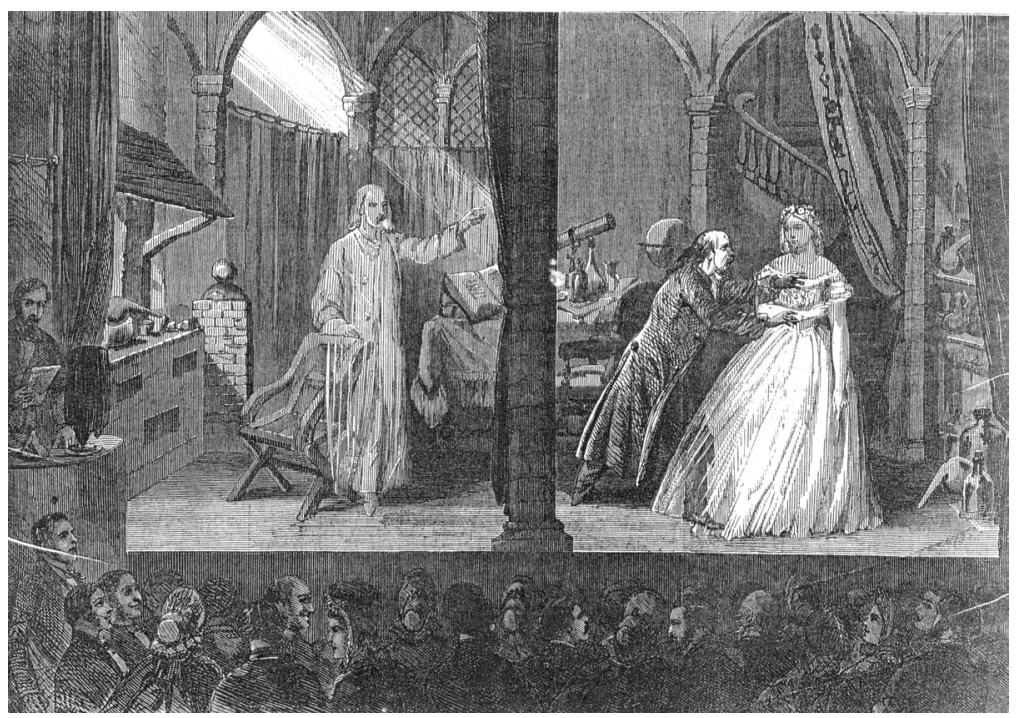

Fig 1 Pepper's Ghost haunts the stage at the Polytechnic Institution. Source: "Spectre Drama at the Polytechnic Institution," Illustrated London News 42 (May 2, 1863), 486.

of workingmen. Now known as "Six Lectures to Working Men," one historian of science has described them as "plebeianizing the Origin" (Desmond 1997, 310). To Huxley's astonishment, when they were published, they sold well and not only in England. In the same year, over at the Royal Institution on Albemarle Street, Huxley's friend John Tyndall, a physicist, was also lecturing to an excited audience. Whereas Huxley lectured to workers, Tyndall's audience was composed of the well to do. Tyndall had the chairman presiding over his spring lecture light a cigar at the invisible focus of a beam of infrared radiation (McMillan and Meehan 1980, 49). The year 1862 is also memorable for the publication of Charles Kingsley's Water Babies in serial form in Macmillan's Magazine. Kingsley, a Christian socialist, novelist, and liberal Anglican cleric, wrote a charming book for children that introduced evolution in a nonthreatening way. In 1862, popularizers of science wrote and lectured for every type of audience in Britain.

But if we traveled across the Atlantic Ocean from Britain to Canada that same year, we would witness another notable event. I refer, of course, to the founding of the Nova Scotian Institution of Science. I have grouped the establishment of the NSIS together with lectures 
by Pepper, Huxley, and Tyndall, as well as with the publication of Kingsley's Water Babies, to illustrate the point of my lecture: that there was a profound connection between the various efforts to disseminate scientific knowledge in 1862 . For some time now, historians have referred to the period between 1848 and 1890 as the age of the worship of science, or sometimes, the cult of science. By this they mean that during this period, at least in the Anglo-American and European world, there was a fascination with science. In Britain in the 1850 's, this fascination manifested itself in a series of natural history crazes, as the marine aquarium and fern collecting became widespread fads. Science captivated the Victorians right up to the end of the century. They came into contact with science through witnessing the spread of dazzling new technologies, such as cable telegraphy, through encounters with exotic animals and plants from around the world, and through experiencing heated debates over the validity of new scientific theories, such as Darwin's theory of natural selection. For some, the fascination with science operated at an even deeper level. For them, science provided the basis for making sense of themselves and their place in the universe, either in conjunction with revised Christian notions or completely on its own terms.

In the past historians have tended to explain the existence of a cult of science as the result of the work of elite scientists like Darwin, Huxley, and Tyndall. But this explanation leaves out two crucial factors: the role of popularizers who were not practitioners of science and the occurrence of a communications revolution in the second quarter of the 1800 s that established the conditions necessary for what happened in the second half of that century. Once these two factors are added to our account of the cult of science, a very different picture emerges that forces us to reconsider the standard story of the dominance of the scientific scene by figures like Darwin, Huxley, and Tyndall. I will outline the major features of the new picture by discussing three modes of popularizing science, in print, in oral form, and in display.

\section{The Communications Revolution}

Published in 1844, a book titled the Vestiges of the Natural History of Creation became the focal point of a huge controversy that reverberated for the rest of the century (Figure 2). In the book the author presented evolutionary theory, previously linked to working-class radicalism, in a favorable, appealing light to middle class readers. The book was attractive to a general audience because it combined 


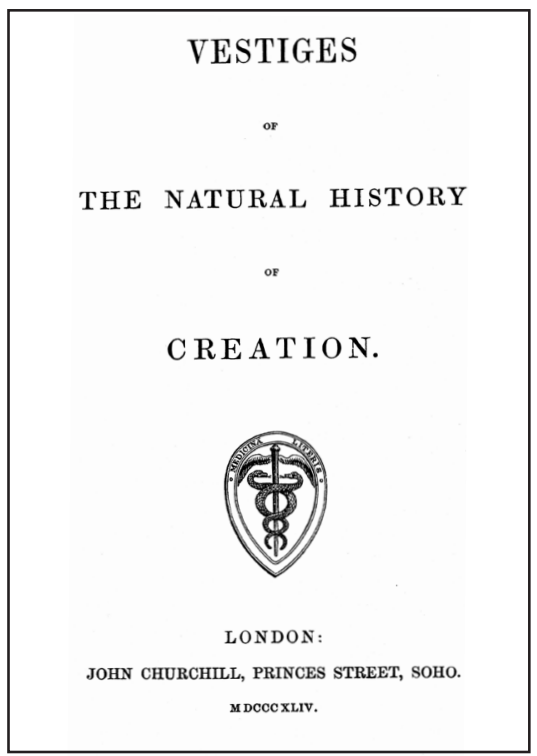

Fig 2 Title page of the first edition of the Vestiges of the Natural History of Creation (1844). Source: [Robert Chambers], Vestiges of the Natural History of Creation (London: John Churchill, 1844).

astronomy, anthropology, psychology, physiology, geology, and theology into a vast synthesis that covered the evolution of the universe from the beginning to the present. The Vestiges provided its readers with a dramatic evolutionary epic, from monad-to-human. Members of the Victorian public were also drawn to the Vestiges because of the mystery surrounding its author. Published anonymously, the author managed to hide his, or her, identity for decades despite efforts to remove the mask. Guessing became a popular game. Some thought the author was Ada Lovelace, who was the only legitimate daughter of Lord Byron, the poet. Others suspected Whig politician Henry Brougham, who championed the publication of cheap books. There was a long list of scientific suspects, including Charles Babbage, the inventor of a calculating engine; Charles Lyell, the eminent geologist; and Charles Darwin, at that time the author of a well-known travel book about his experiences while on HMS Beagle (Secord 2000, 20-21).

Selling 39,000 copies by 1890 , the Vestiges was an extraordinarily successful scientific steady seller. To put the book's sales into context, let us compare them with the sales of Darwin's Origin of Species, published in 1859. Darwin's Origin reached the 56,000 mark by 1899 , 
surpassing the Vestiges. But in terms of the immediate impact of the two books, the Vestiges outsold the Origin. Whereas the Vestiges sold 21,250 copies within a decade of its first publication, the Origin sold only 10,000 copies (Lightman 2007a, 33-34). There is no doubt that Darwin's book had an enduring impact, unlike the Vestiges. But from the point of view of the Victorian reader in the middle of the century, the two books were almost on a par in terms of influence. So who was the author of the Vestiges? The answer to the question is quite revealing. The author was not a practitioner of science-he was a publisher and a writer. Robert Chambers was one of the brothers behind the Scottish firm W. and R. Chambers that was moving in the 1840's into the world of large-scale, cheap book publishing. With their experience in periodical printing, the Chambers publishing firm was well positioned to take this new path. Due to Chambers's Edinburgh Journal (f. 1832), the firm had established a reputation as "publishers for the people." They aimed their publications at a new polity of consumers composed of middle- and working-class family readership. When Chambers wrote the Vestiges he drew on all of his experience as a publisher and journalist for this audience. This is why he was able to make evolutionary theory appealing to his readers. He knew his audience and what they liked to read.

The sales of Chambers' Vestiges were important to other publishers of the 1840's. They offered proof that a new reading audience existed for cheap science books. Previously, this had not been the case. Publishers had experimented with similar publishing projects earlier in the century, and the results had been mixed. Experiments in cheap educational publishing began in the second decade of the nineteenth century, in the wake of the transformation of the book trade. These ventures were crucial in the development and definition of "popular" publishing in general and "popular science" in particular. Cheap children's books published by Longman and Richard Phillips, and William Pinnock's educational catechisms, were followed by the inception of the new weekly periodicals. Relatively inexpensive literary journals such as Literary Gazette (1817) and Literary Chronicle (1819) were founded, along with the new two- and three-penny weeklies, such as the Mirror of Literature (1822), the Mechanic's Magazine (1823), the Lancet (1823), and the Chemist (1824). The children's books and the weeklies of the 1810 s and early 1820 s confirmed the existence of a new and profitable market for cheap 
publications. This led to the production in the 1820s and 1830s of publications by the Society for the Diffusion of Useful Knowledge (SDUK), and by John Murray and Longman with the designation "popular science." These ventures had limited success.

But for cheap science books and periodicals to reach sales of the magnitude of the Vestiges consistently, the conditions had to be right. First, there had to be readers who would buy the books. In this context, it is useful to examine literacy rates in Britain. The size of the British reading audience grew, as literacy rates increased dramatically over the course of the last sixty years of the century. Whereas the number of literate and illiterate Britons was roughly equal at the end of the 1830 s, by the close of the century illiteracy had fallen to 1 percent (St. Clair 2004, 13; Vincent 1989, 22). Starting in the 1830s, then, publishers could reach out to a growing reading audience as new segments of the population became literate, especially members of the middle class and the wealthier working class. It is difficult today, when we are bombarded with print on a daily basis, to imagine a western society where the ability to read was so restricted. But it would be fair to say that a mass reading audience, as we know it, did not exist in Britain at the end of the eighteenth century. And that is why we cannot really speak of the existence of "popular science" before the beginning of the nineteenth century.

If the nature and size of the reading audience was evolving in the first half of the nineteenth century, so was the technology of publishers. The new steam powered publishing technologies under development would eventually allow publishers to reach the rapidly growing reading audience. Many steam-printing technologies developed in the early nineteenth century had been used by newspaper and penny periodical publishers who saw the advantages of faster production, but not book publishers, who relied on hand-press technology. In the 1840s, some book publishers decided to attempt to reach the audience of the penny periodicals and began to adopt steam-print technologies. The growth of the British railway system provided a better transportation system for publishers and the reduction of the cost of paper and the "taxes on knowledge", an intricate system created to prevent radicals from publishing, made it even more possible to produce cheap publications. James Secord, an eminent historian of science who has written extensively about Chambers and the Vestiges, has argued persuasively that all of these developments combined to 
create a communication revolution. He asserts that this revolution represented the "greatest transformation in human communication since the Renaissance" that led to "opening the floodgates to a vastly increased reading public" (Secord 2000, 2).

Let us not forget that during the second quarter of the nineteenth century, an important period for the communications revolution, was also the time when the mechanics' institutes really took off. The Whig politician Henry Brougham's Practical Observations upon the Education of the People (1825) was one of the catalysts. In his Political Observations, Brougham set down a general plan for establishing and managing such institutes throughout Great Britain. He was also involved in the vast publishing experiment known as the Society for the Diffusion of Knowledge. His plans to set up a Society to publish cheap science books are of a piece with the idea behind the mechanics institutes. Institutes began to appear in many large British towns by the 1840's. By 1851 there were over seven hundred literary and mechanics institutes in Great Britain and Ireland with over 120,000 members. This year was the high point of their expansion. Organized by interested members of the middles classes for artisans and operatives, the belief was that scientific education would result in the moral improvement of these members of the working class and that it would lead to their acceptance of the new industrial society (Shapin and Barnes, 1977, 33-37). The NSIS was a direct descendant of the Halifax Mechanics' Institute (1831-1860) and of the Halifax Literary and Scientific Society (1839-1862). So the intertwined stories of mechanics institutes and the communications revolution during that period are important for understanding the early history of the NSIS.

\section{Scientific Authors}

Even with the increase in the literacy rate leading to the growth of new reading audiences for science, and the development of new printing technologies by the publishers, a third requirement was needed to make possible the production of cheap science books. Someone had to write them. In the past, historians have concentrated on the science books written by practitioners, the men who did science. For the second half of the nineteenth century this would mean looking at the Huxleys and the Tyndalls, members of the scientific elite bent on professionalizing science. But these men had a specific agenda to pursue that affected their popularizing activities. When Huxley's 
generation of scientific practitioners arrived on the scene at the midpoint of the century, a changing of the guard took place within the scientific leadership, though it was not without friction. Many of the middle-class "Young Turks" of science, including Huxley and Tyndall, came from outside the Oxbridge environment. Where the earlier generation of British scientists had insisted that knowledge was to be conceived within a religious framework, the aims of this new group included the secularization of nature, the professionalization of their discipline, and the promotion of expertise. Huxley coined a catchy name for this new vision of a science emancipated from theology: scientific naturalism. Huxley argued that proper science excluded any reference to a divine being - scientists should stick to studying observable causes and effects in nature. The scientific naturalists aggressively pushed for a redefinition of science in the latter half of the nineteenth century. In addition to Huxley and Tyndall, the ranks of the scientific naturalists included the philosopher of evolution Herbert Spencer, the mathematician William Kingdon Clifford, the founder of eugenics Francis Galton, the statistician Karl Pearson, the anthropologists John Lubbock and Edward Tylor, the biologist E. Ray Lankester, the doctor Henry Maudsley and a group of journalists, editors and writers such as Leslie Stephen, G. H. Lewes, John Morley, Grant Allen and Edward Clodd.

The scientific naturalists were not just aiming at a reform of scientific theories and institutions. They were also interested in transforming British culture as a whole. They put forward new interpretations of humanity, nature and society derived from the theories, methods and categories of empirical science, especially evolutionary science. They chose to challenge the cultural authority of the Anglican aristocratic establishment by claiming that they provided the best intellectual leadership of a modernized and industrialized Britain. When they wrote books, articles or lectures for the Victorian public, they defended the agenda of scientific naturalism.

But by focusing only on the practitioners of science when trying to understand how science was communicated to a general audience, we completely miss another large group of popularizers, the scientific journalists and writers. These men and women usually had no formal scientific training. Often they were self-taught. Many of them were trying to establish a career for themselves as science writers, taking advantage of the new market conditions and the need of publishers for authors. This was the beginning of science journalism as a 
profession. From the point of view of the scientific naturalist, these popularizers presented a problem. They did not have the expertise needed to speak on behalf of science. Many of them did not share the agenda of the scientific naturalists. But the scientific naturalists had little control over who publishers and editors hired to write about science. They would have been particularly concerned about the large number of Anglican clergymen and women who were churning out science books. Due to their naturalistic approach to science, Huxley and his allies were committed to eliminating the clergymen-scientists who saw the study of nature as a handmaiden to natural theology or as subordinate to theology and religious authority. As for women, in the eyes of the scientific naturalists they were doubly disqualified from real participation in science, including the role of popularizer. Not only were they more easily seduced by the lure of Christianity, they were considered not to possess the required intellectual power to engage in genuine scientific research. By nature they were religious, emotional, and subjective, according to the scientific naturalists. Darwin's Descent of Man (1871) provided an evolutionary rationale for the alleged inferiority of women. Writing to the geologist Charles Lyell on March $17^{\text {th }}, 1860$, T. H. Huxley declared, "five sixths of women will stop in the doll state of evolution, to be the stronghold of parsondom" (Imperial College, Huxley Papers, 30.34).

It is therefore somewhat surprising to find that there were a large number of Anglican clergymen and women engaged in popularizing science in the second half of the century. Among the Anglican parsons were Ebenezer Brewer, Charles Alexander Johns, Charles Kingsley, Thomas William Webb, Francis Orpen Morris, George Henslow, William Houghton, and Henry Neville Hutchinson. These men drew on their authority as clergymen of the Church of England to speak in public about their views on science. They established themselves as trusted writers in a wide range of scientific areas, from astronomy to botany, entomology, geology, and ornithology. Through their work the Church of England maintained an active presence in the British scientific world, and they kept the relevance of religious themes to contemporary science before the minds of the public, even after the appearance of Darwin's Origin of Species.

Let us take Ebenezer Brewer as an example of this group of popularizers. Brewer was a graduate of Cambridge (Figure 3). He was ordained Deacon in 1834 and priest in 1836, but he never seems to have held an ecclesiastic post. Although headmaster of King's College 


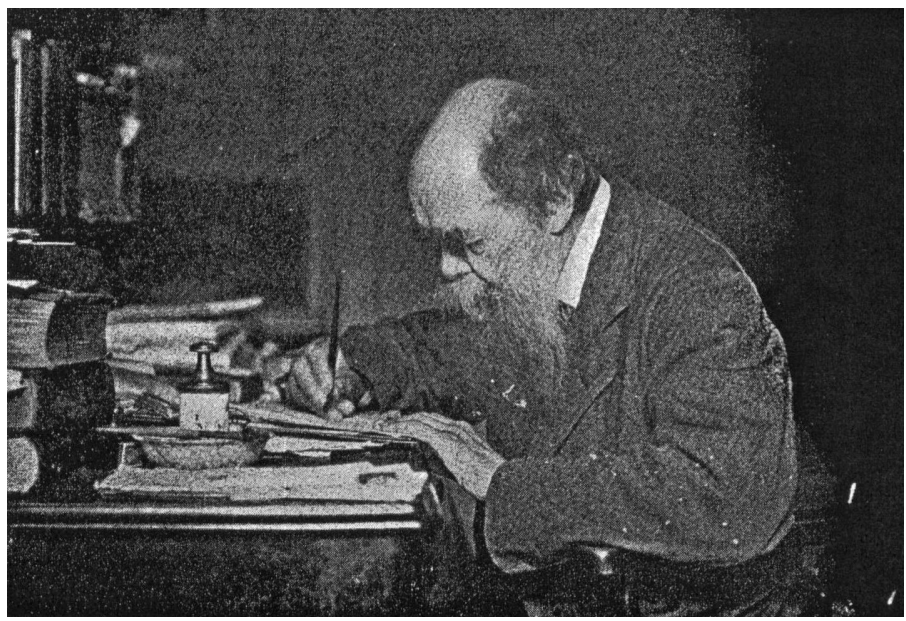

Fig 3 Brewer at work at his desk. Source: The House of Jarrolds, 1823-1923: A Brief History of One Hundred Years (Norwich: Jarrold Publishing, 1924), opposite p. 41.

School, Norwich, he dedicated himself to writing books on a wide range of topics, including the literary, social, and political history of Europe, book-keeping, dictionaries of phrases and fables, school textbooks, and scientific works aimed at a popular audience. Brewer's Guide to the Scientific Knowledge of Things Familiar (1847) holds the record for largest number of copies sold of a science book published in the second half of the nineteenth century. By 1892, when the book had reached its forty-fourth edition, 195,000 copies had been printed (Lightman 2007a, 66). That is over three times the number of copies of Darwin's Origin sold by 1899. The book used a question and answer format familiar to audiences through their reading of religious catechisms. Here are some samples of his questions and answers. "Q. Show the wisdom of God in making AIR a BAD conductor." The correct response was, "If air were a good conductor (like iron and stone), heat would be drawn so rapidly from our body, that we should be chilled to death." Many of his questions challenged the reader to link established scientific facts to divine wisdom or goodness. "Q. Show the WISDOM of GOD in making grass, the leaves of trees, and ALL VEGETABLES, excellent radiators of heat" (Brewer 1874, 184, 215).

Women also distinguished themselves as popularizers of science in the second half of the nineteenth century. They wrote about vir- 
tually every aspect of the natural sciences, though natural history topics tended to dominate. Lydia Becker, Phebe Lankester, Anne Pratt, Elizabeth Twining, and Jane Loudon all explored the world of botany. Arabella Buckley and Alice Bodington wrote primarily on evolutionary biology, while Margaret Gatty was more interested in marine biology. Other women, such as Mary Roberts, Anne Wright, Sarah Bowdich Lee, Annie Carey, Eliza Brightwen, and Elizabeth and Mary Kirby, moved across topics in natural history, from geology, to conchology, ornithology, and entomology. A smaller number of women tackled natural philosophy. Agnes Clerke and Agnes Giberne concentrated on astronomy. Some women were knowledgeable enough to range over both the physical and life sciences. Mary Ward covered astronomy in one book and the use of the microscope to study livings things in the other. Rosina Zornlin penned works on electricity, geology, geography, astronomy, and hydrology. Mary Somerville began with astronomy, but also dealt with other physical sciences and the life sciences in later books.

Margaret Gatty is an example of one of the women (Figure 4). Gatty, a devout evangelical, was married to a Yorkshire clergyman. She wrote a number of widely read books on zoological topics. Her British Sea-Weeds (1863), an introductory book to the topic, established her credentials as a knowledgeable collector, but her series of didactic and scientifically informed short stories, Parables from

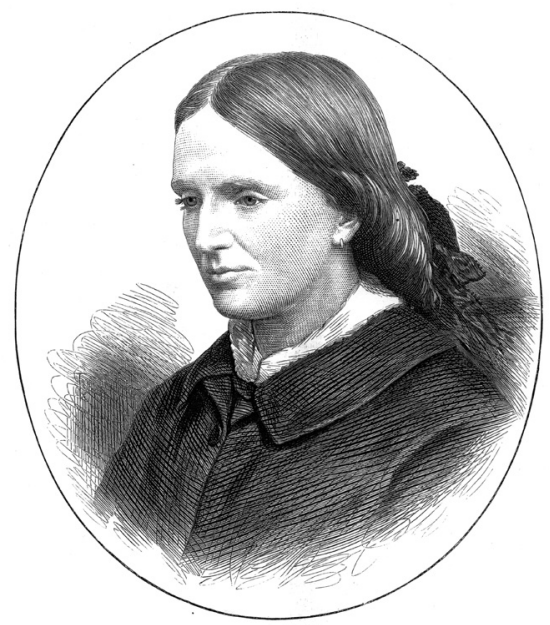

Fig 4 Margaret Gatty, an evangelical popularizer of science. Source: "The Late Mrs. Alfred Gatty," Illustrated London News 63 (October 18, 1873), 379. 
Nature (1855-71), became an international bestseller that made her a household name in Britain. Reaching an eighteenth edition in 1882, it was reissued many times by different publishers right up to 1950 . Gatty's Parables contained a mix ture of science, morality, and religion that was considered to be appropriate Sunday reading for Victorian families. Gatty's evangelicalism was reflected in her stories, and she was fiercely opposed to Darwin. Women like Gatty, and Anglican clergyman like Brewer, had much in common. Their authority to speak out on the religious significance of science was being questioned by the scientific naturalists. They both emphasized the moral and religious lessons to be learned through an understanding of nature, and they stressed the sense of wonder to be experienced when faced with its beauty. Together, they formed a formidable group whose common agenda could frustrate the goals of scientific naturalists.

\section{Scientific Lecturers}

John George Wood, popularizer and Anglican clergyman, delivered the Lowell Lectures in Boston in 1883. He startled his audiences with a carefully managed spectacle. To illustrate the key points of his lecture he drew "rapid improptu sketches" of creatures that gradually took shape before the eyes of those attending. Audiences were particularly impressed by their magnitude. The sheet of black canvas that he used to draw on was stretched on a wooden frame that gave him a surface of eleven feet by five feet six inches. Close up, the drawings looked coarse and clumsy, but when viewed from thirty or forty feet away they were elegant pictures that were clearly visible in every part of the largest hall. The impact on the audience was electrifying. In one of his Lowell Lectures Wood spoke on the whale to a packed room. "When I opened the lecture by drawing the whale, eleven feet long, in two strokes," he wrote to his family, "there was first dead silence, and then such a thunder of applause that I had to wait." Then Wood drew a little sailor on the whale's back to illustrate its gigantic size, and the crowd "laughed and cheered in the heartiest manner" (T. Wood [1890], 203). Wood's larger-than-life sketches catered to the popular audience's taste for spectacle. He realized that if science lectures were to become a popular form of entertainment, and if he were to succeed as a public lecturer, he had to satisfy the craving for visual images that was the hallmark of mass culture in this period.

Wood was among the most well known popularizers in the second 
half of the century. He lectured and published extensively. He turned his lectures into spectacles and incorporated a multitude of visual images in his books. In this section I will examine Wood as a representative showman of science. Many science lecturers capitalized on the pictorial turn in British culture. In addition to Wood, the natural historian Frank Buckland, son of the eminent Oxford geologist William Buckland, and Richard Proctor, a prolific popularizer of astronomy, exploited their audience's hunger for spectacle and visuality. Appealing to the eyes of their audience gave them a competitive edge and provided them with a powerful vehicle for presenting a vision of science set within a religious framework. They demonstrated the potential of science to attract vast, new audiences by incorporating visual spectacle. Their blend of instruction and amusement was a hallmark of popular science in this period. But some were able to make a good living from their lecturing while others struggled. Wood was one of those who struggled.

Wood, like Brewer, is another one of those figures who were well known to Victorian audiences but who have been forgotten by historians, until recently. A reviewer in the Saturday Review, who was by no means well disposed towards Wood, acknowledged that he "had a thousand readers where Darwin had but one and Professor Huxley not more than a dozen" (“Rev. J. G. Wood” 1890, 479). The phenomenal sales of Wood's books confirm that he had a large reading audience. His Common Objects of the Country (1858) became one of the best-sellers of the second half of the century. Within a decade of the book's first appearance, 64,000 copies had been printed, and by 1889 , the number was 86,000 copies (Archives of George Routledge \& Co. 1853-1902, 1973, Publication Books, vol. 2, 424; vol. 3, 87, 96; vol. 5, 324; vol. 6, 96). This far exceeded the sales of Darwin's Origin of Species. When the Victorian reading public thought about science, they were as likely to recall books by Wood, as they were to refer to Darwin's Origin. It was a sign of Wood's popularity when Punch poked fun at his Wood's Common Objects of the Seashore (1857) and those who read it by depicting them as if they were the common objects of the sea when they combed the shore for marine flora and fauna (Figure 5). Wood received his B.A. from Oxford in 1847 and was ordained as priest in 1854 (Figure 6). But already his interest in natural history was leading him away from a clerical career. After several of his natural history books had been well received by 


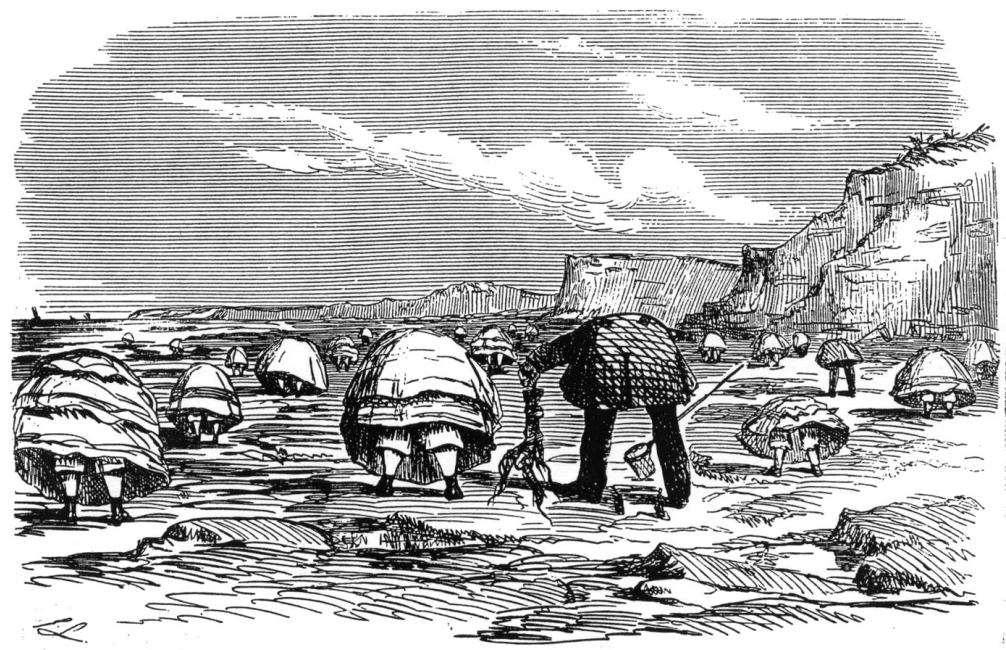

Fig 5 Punch lampooning Wood's readers. Source: "Common Objects at the Sea-SideGenerally Found upon the Rocks at Low Water," Punch 35 (August 21, 1858), 76.

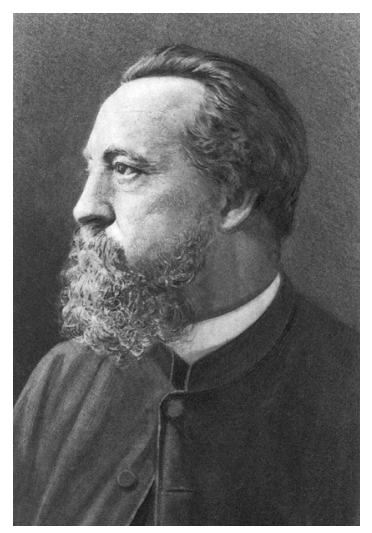

Fig 6 The Reverend J. G. Wood, Anglican clergyman turned popularizer of natural history. Source: Theodore Wood, The Rev. J. G. Wood: His Life and Work (New York: Cassell Publishing Company, 1890), frontispiece.

Victorian readers, Wood resigned in 1862 from all paid clerical duties and began to build a career as a scientific writer. Leaving the security of a clerical position for writing was a risky move, particularly in the early 1860 s. Wood could only make it work by churning out articles and books at an astounding rate. He published over two dozen natural history books over the course of his career as a popularizer. 
Wood was known for his lavishly illustrated books. In Insects at Home (1872), for example, there were seven hundred figures drawn by a team of illustrators. Insects Abroad (1874) contained six hundred illustrations produced by the same team. Wood's illustrations played an important role in his presentation of a theology of nature that would have been opposed by the scientific naturalists. In the preface to Insects Abroad, he stated his two objectives. First, in keeping with the goodness of divine design, he hoped "to show the great and important part played by Insects in the economy of the world, and the extreme value to mankind of those insects which we are accustomed to call Destructives." The creatures most detested by humans - mosquitoes, ants, and wood-boring beetles and termites - were actually among our greatest benefactors. According to Wood, insects were "working towards one purpose, namely, the gradual development of the earth and its resources." Insects were not just good in the larger scheme of things; they were also beautiful. The second objective of Insects Abroad was to encourage readers to "note the wonderful modifications of structure which enable the insects to fulfill their mission, and the surpassing beauty with which many of them are endowed" (J. Wood 1883, v, 5). Insects at Home also emphasized this theme. "We find among insects," Wood asserted, "a variety and brilliancy of colour that not even the most gorgeous tropical flowers can approach, and that some of our dullest and most insignificant little insects are, when placed under the revealing lens of the microscope, absolutely blazing with natural jewellery" (J. Wood 1872, 2).

Throughout both books, Wood drew the reader's attention to the beauty of insect bodies and wings, making good use of his many illustrations. The illustrations in the insect books presented their subjects in a natural setting filled with lush vegetation and teeming with life. This was the vision of nature so central to natural theology. The striking frontispiece to Insects at Home, rendered in vivid color, presented a variety of different insects, including one of Wood's favorites, the Great Green Grasshopper. This is Wood's happy world of beautiful insects. It was no challenge for Wood to highlight the beauty of some butterflies, moths and beetles. But he was not satisfied unless he could persuade his readers that nearly every insect was aesthetically pleasing in some way. As Wood turned to insects commonly seen as ugly and disgusting, he found something attractive and wonderful to praise (Figure 7). A giant earwig, on the right near the bottom of 


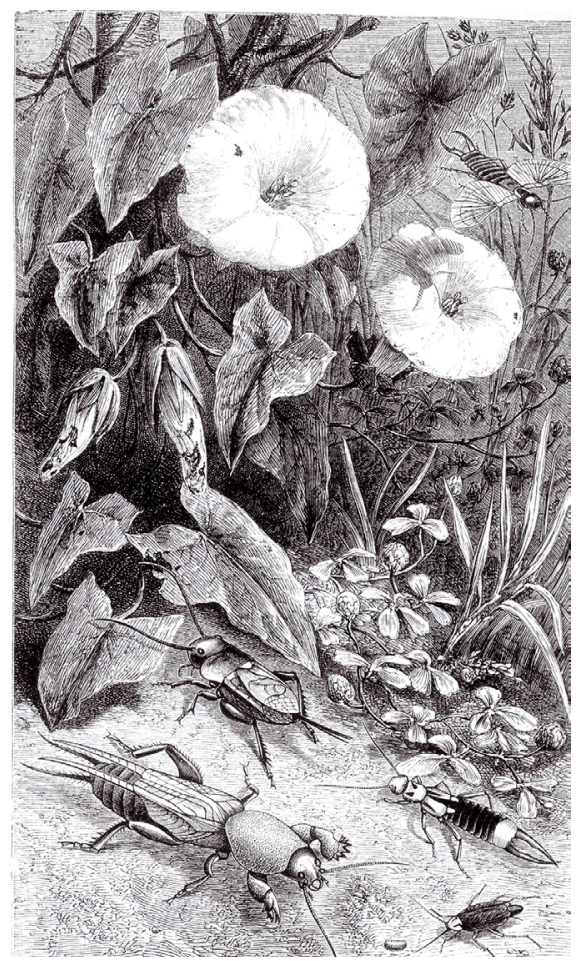

Fig 7 Finding wonder in the insect world. Source: John George Wood, Insects at Home (London: Longmans, Green, 1872), 228, plate VII.

Plate VII of Insects at Home, was described as a "fine insect," while the common earwig, on the right near the top, was shown with "its beautiful wings extended." In this illustration Wood also includes a field cockroach and its egg case (bottom right), a field cricket (just below the center of the illustration), and a mole cricket (center bottom, below the field cricket). In some cases Wood was forced to turn to the microscope for help in finding the element of beauty he wanted his readers to see in all insects. As "dull and colorless as the Gnat may appear to the unaided eye," Wood announced, "it has only to be placed under the revealing glass of the microscope to blaze out in a magnificence which would pale all the fabled glories of Aladdin's fairy palace" (J. Wood 1872, 226, 230, 602).

Wood found that he could not always make enough money to support his family just by publishing books. In the later 1870's, when the state of the book trade had deteriorated, Wood began to consider 
lecturing as a possible means of supplementing his income. From 1879 until his death in 1889 , Wood conducted ambitious lecturing tours of England, averaging about ninety lectures in a season. During his most extensive tour during the 1881-82 season, Wood gave more than 120 lectures. Wood was in competition with professional scientists like John Tyndall who had tremendous reputations as powerful speakers and great showmen. Wood's use of his "rapid impromptu sketches" of battling ants, gigantic whales, and other creatures won him scores of invitations to lecture. Wood used color pastels imported from Paris that positively glowed on the large, black canvas-drawing surface that he had specially designed. Unfortunately, none of the sketches have survived. We can only try to get a glimpse of what they looked like from contemporary reports. A reporter for the $A l$ trincham and Bowdon Guardian was deeply impressed by Wood's sketches, which were "not mere diagrams, but finished pictures in colours of great beauty." In his estimation, "Mr. Wood's method of lecturing is in fact we believe, unique" ("Lectures for Altrincham and Bowdon" 1881, 5). According to Wood's son, the sketches were "always perfectly exact in every particular," and "no line was ever rubbed out or alteration ever made." Wood's seemingly spontaneous sketches were the outcome of long and careful prior preparation. First, he made a tracing of the object he wished to draw from some trustworthy woodcut. He would copy this two or three times upon a slate, always attempting to do so with the fewest possible lines. Next, he would make a very careful sketch in color upon the back of a small paper strip. Then, finally, he would stand before his black canvas and practice drawing the sketch over and over until he could execute it without hesitation and without mistake. Wood's command of his pastels in the accurate depiction of the natural world served as proof of his scientific expertise (T. Wood [1890], 154, 159).

Wood's innovative speaking style won him the invitation to give the prestigious Lowell Lectures in Boston. The trip was a success in terms of the enthusiastic response Wood received from his audiences. But Wood's failure to hire an agency to organize engagements in addition to the Lowell Lectures doomed the enterprise financially, and he would have made just as much had he stayed in England. His second transatlantic tour in 1884-5 was a disaster and was cut short. This time he had hired an agent, but an incompetent one who lied to Wood about the number of firm engagements. After that 
experience Wood decided never again to undertake another trip across the Atlantic.

The circumstances surrounding Wood's death also underlined the risk involved in trying to make a living off scientific lecturing. Once Wood started lecturing, the physical demands of the circuit took its toll on his health. Wood caught a severe chill while on a lecturing tour and then died shortly thereafter, on March 3, 1889. "The poor fellow literally died in harness," one of Wood's friends wrote in the Times. The friend was making a plea on behalf of Wood's family, whom he had left totally unprovided for. Donors were asked to send money to the "J. G. Wood Fund." Shortly thereafter, Wood's widow wrote to the Royal Literary Fund for help. "So impossible did he find it to maintain his family by his pen alone," she explained, "that in 1879 he adopted public lecturing as a supplementary profession and yet after working almost without a days' holiday for nearly 37 years, he has been able to leave behind him nothing but the proceeds of his life insurance policy" (Whitehead 1889, 15; Cambridge University Library, Royal Literary Fund, File No. 1982, Letter 24). Although Wood's unhappy demise demonstrated the riskiness of embarking on a career of popularizing science, he was nevertheless highly influential with the public. His influence owed a great deal to his use of visual images in both his popular lectures and his best-selling books. He offered a theology of nature, depicted in images of harmonious animal life, that countered the secularized vision of nature propounded by scientific naturalists like Huxley and Tyndall.

\section{Museums and Exhibitions}

In 1851 London was the site of an international exhibition. The Great Exhibition of the Works of Industry of All Nations was a significant indicator of a change in attitude toward science evident to many mid-nineteenth-century observers. Historians have presented it as proof of the beginning of the age of the cult of science. The Exhibition was housed in an immense glass and iron building of unique architectural design, earning it the nickname "Crystal Palace." Never before had an industrial exhibition drawn such huge crowds. T. H. Huxley, then an aspiring young biologist, wrote to his future wife in 1851 that visitors to the Crystal Palace approached it with awe and reverence, as if they were on a sacred pilgrimage to a holy shrine. "The great Temple of England at present," Huxley told her, "is the Crystal Palace-58,000 people worship there every day. They come 
up to it as the Jews came to Jerusalem at the time of the Jubilee" (Huxley to Heathorn, September 23, 1851, letter no. 165-66, Imperial College, Huxley Papers, Huxley/Heathorn Correspondence). If the success of the Vestiges indicated to publishers that there was a market for cheap science books, the throng of visitors to the Crystal Palace seemed to show that exhibitions that featured science and industry could be popular draws.

The nineteenth century was also a period of museum growth. Existing museums were expanded and new museums were founded, especially after the Museums Act of 1845 in Britain enabled civic museums to be established throughout the provinces. As well as such great national museums as the National Gallery (founded in 1824) and the South Kensington Museum (1857), which was the precursor of the both the Victoria and Albert Museum and the Science Museum, two hundred metropolitan, provincial, and university museums were founded in Britain (Rupke, 1994, 13-15). Among them were important science museums, such as the Museum of Practical Geology (1851) and the British Museum (Natural History) in South Kensington (1881). In addition to these museums of public education, there was a wide range of more commercial enterprises, ranging from the relatively long-term - such as the Adelaide Gallery (1832-45) and the Polytechnic (1838-81) - to such ephemeral shows as the exhibitions of the so-called Aztec children who took London and Dublin by storm in the summer of 1853. At the start of the century, access to most museums had been governed by gentlemanly conventions of politeness, and some collections remained in gentlemen's private cabinets located in country houses, where they were accessibly only to polite or respectable classes of society. But by the end of the Victorian era, most museums had been opened up, from the country houses, which welcomed hordes of day-trippers, to the national and municipal museums, which were open to all at no cost and even began to open on Saturdays and evenings. The formation of a mass reading public in Britain, therefore, took place at about the same time that museums and exhibitions became accessible to a mass visiting public. Of course, these publics were virtually one and the same.

The world of Victorian science exhibitions and museums is fascinating. A number of examples illustrate their significance. Wyld's Globe, constructed in 1851 as a companion to the Great Exhibition, is one candidate. Located in the heart of Leicester Square, London, 
visitors could walk into a massive globe that contained a huge map of the earth on the inside. The purpose of the Globe was to educate the public in the science of geography, and lecturers were stationed at various points to inform visitors about that particular part of the globe. Later, new attractions were added, including a panorama of China, dioramas of India and of the Australian gold fields, models of the Arctic and of the Crimean War, and an Oriental Museum. The Globe stayed open for ten years, drawing large crowds. Another candidate is the Royal Panopticon, also in Leicester Square, which was built in 1854 and closed two years later. It featured an immense organ, a large fountain, a gigantic electrical apparatus, industrial machines, scientific instruments, sculpted statues, tradesman's stalls, a laboratory, an apparatus room, a photography gallery, and lecture halls. But I will focus on a third intriguing scientific institution, the Royal Polytechnic Institution. That will allow us to return to John Henry Pepper and his ghost illusion. What all three had in common was an emphasis on entertainment and instruction, which was also a feature of the books and lectures we have discussed.

Pepper became manager of the Royal Polytechnic in 1854 (Figure 8). Educated at King's College School, he later studied analytic chemistry at the Russell Institution. In 1840 he was appointed assistant chemical lecturer at a private school of medicine. His relationship with the Royal Polytechnic Institution began in 1848, when he was hired as a lecturer and analytic chemist. Pepper was manager for eighteen years, with some short interruptions. But he resigned for

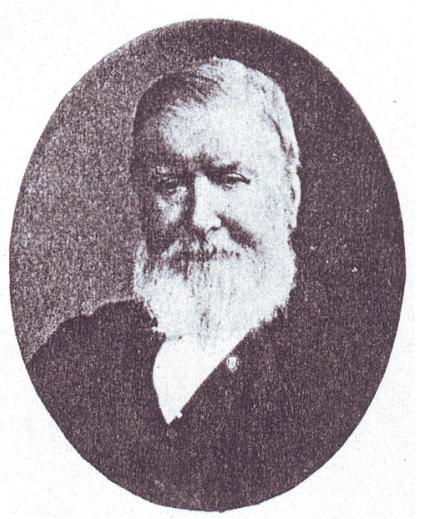

Fig 8 John Henry Pepper, showman of science. Source: "Personal," Illustrated London News 116 (April 14, 1900), 503. 
good in 1872 after a quarrel with the board of directors over the extent of his autonomy. During his time at the Polytechnic, he published five science books for the public, including The Boy's Playbook of Science in 1860. After leaving the Polytechnic, he tried to re-create his form of science entertainment at the Egyptian Hall in Piccadilly but lost money on the venture, and he went on tour in the United States, Canada, and Australia from 1874 to 1881 . He accepted the post of public analyst in Brisbane, Australia, in 1881, stayed there until 1889 , and then returned to England, where he remained until his death in 1900 (Boase 1965, 386-87; Cane 1974-75, 116-28; Secord 2002, 1648-49; Brock 2004, 1572-73).

When Pepper took over the reins of the Polytechnic in 1854, the big question for the manager of this institution was how to attract customers whose expectations had been raised by their experiences exploring the Crystal Palace on shilling days. The Polytechnic's offerings must have seemed meager in comparison. When it was first established in 1838, the Polytechnic seemed vibrant and novel. It was equipped with a laboratory, a lecture theater, industrial tools and machines, and a large display room, known as the Great Hall, where the main exhibits were housed. Among the main exhibits were the diving bell and diver, an oxyhydrogen microscope, large electrical machines, and model boats floating in a long canal (Figure 9). The diving bell provided a unique experience for visitors. Four to five persons could fit inside while it was submerged. Given the diversity of its attractions, the Polytechnic was part museum, part laboratory, part lecture theatre, part exhibition hall, and even part amusement park. But Pepper transformed the Polytechnic in an effort to attract more visitors in the competitive post-Crystal Palace era. He added features associated with the London entertainment scene. In the 1850's he added dramatic readings - mainly from Shakespeare - and then experimented with scenes of plays and then entire plays.

Pepper took the theatrics of science to a whole new level when he came across a new scientific principle for generating surprisingly realistic optical illusions suggested by the inventor Henry Dircks. Pepper had already been lecturing on "Optical Illusions" in 1856 and on "Remarkable Optical Illusions" in 1857 and saw this as an area that could attract a substantial audience. Dircks' invention, improved by Pepper, gave him an almost unlimited source of new illusions that attracted vast crowds to the Polytechnic. The ghost illusion was used in various scenes accompanying Pepper's lectures while the 


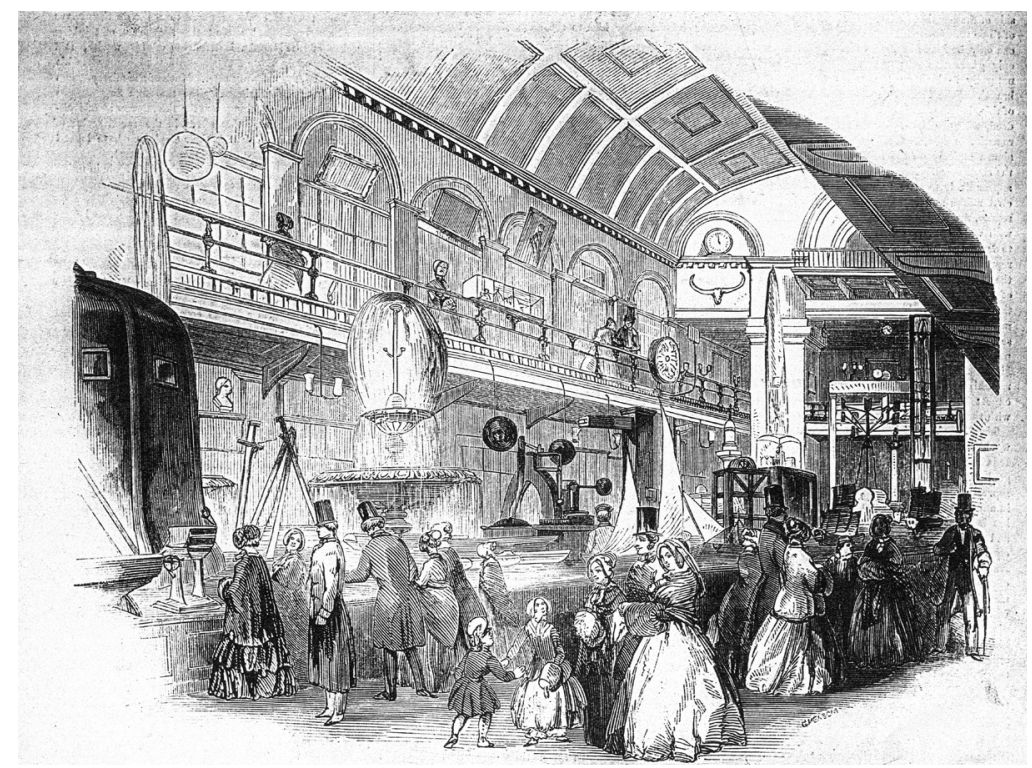

Fig 9 The Diving Bell at the Polytechnic, at left in the picture. Source: University of Westminster Archive, R Illust 10. Reproduced with permission of University of Westminster Archive Services.

"Spectre Drama" played in the morning and the evening. Special written permission was obtained from Charles Dickens to mount a production of his "Haunted Man" as a vehicle for exhibiting the ghost illusion. To satisfy the craving for novelty, Pepper was constantly modifying his illusions so he could present a variety of startling effects. In 1865, visitors to the Polytechnic could see the disembodied head of Socrates deliver a rhymed speech and Sir Joshua Reynold's cherubs singing a choral song. To the disembodied head of Socrates he added Shakespearean creations including the floating and speaking heads of Hamlet and Lear. Pepper's theatrical use of the ghost in his lectures and the dramatic productions at the Polytechnic were, to him, completely in line with the scientific aims of his institution. Pepper's lectures stressed the optical science behind his illusions. Though entertaining and spectacular, his lectures were intended to be instructive (Lightman 2007b, 111-124). The public never seemed to tire of his optical illusions (Figure 10). In 1866, the Illustrated London News claimed that 109,000 visitors had seen them ("Royal Polytechnic" 1866, 511). 


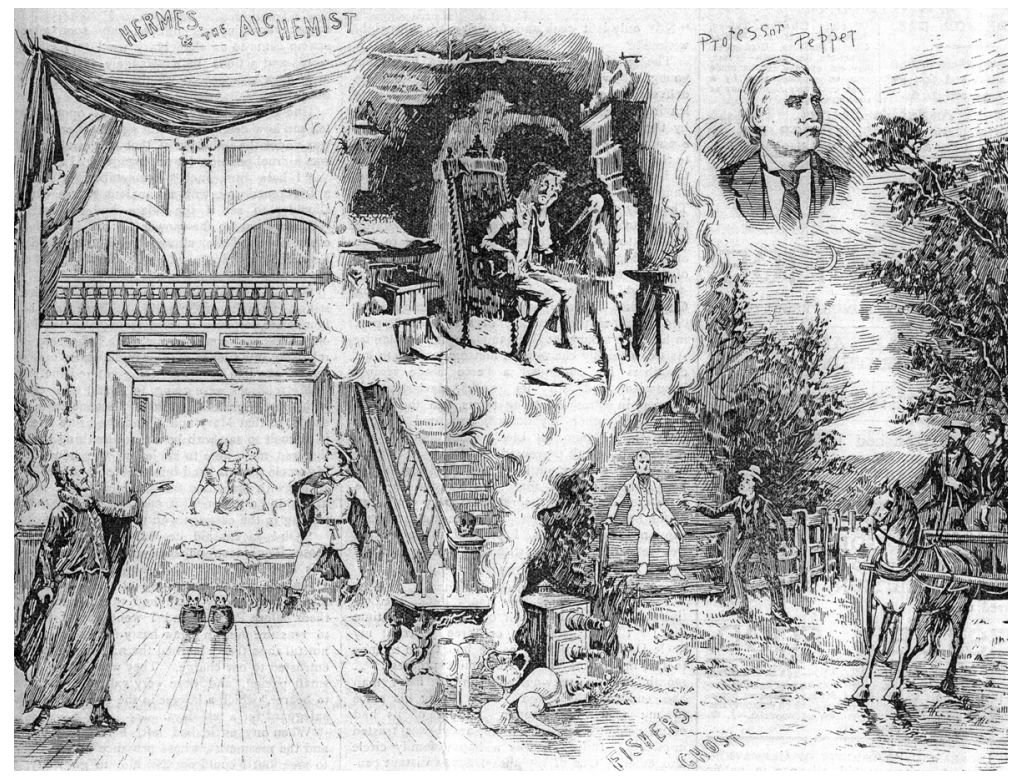

Fig 10 Pepper's Ghost Illusions. Source: "Professor Pepper and His Ghosts," Pall Mall Budget (January 16, 1890), 85.

Besides the impressive figures on the number of visitors who went to the Royal Polytechnic Institution, we can also gauge the Polytechnic's impact by looking at cultural references to it from outside the scientific world. During the 1860s, a humorous song about the Polytechnic began to circulate. It was titled "Laughing Gas or A Night at the Polytechnic." The song tells a story about a young man from rural England, Humphrey Brown, who has come to London to visit all of the popular London entertainments, including the Polytechnic (Nash [1860]). Exhausted by his busy day, Brown falls asleep in the lecture room and awakens to find that he is locked in for the night. Afraid of meeting one of Pepper's ghosts, he shores up his courage by swallowing the contents of a container marked "Improved Laughing Gas." He begins to feel light headed, as if he were drunk, and laughs uncontrollably. Then he explores the Polytechnic in this peculiar condition, playing with all of the exhibits. He sees Cherubs floating about in the air; puts on a diving suit, and gets a huge shock from one of the electrical apparatus. Pepper returns and finds him, and tells him that that he has ingested so much gas that he'll laugh until he dies. 
The composer and singer of the song, John Nash, was a well-known music-hall artist and comedian. He performed at the South London Music Hall in 1860 and then at the Oxford Music Hall the following year. He toured the United States in 1874 and in 1876 and later formed his own touring company that he took across the Atlantic in 1886. He was the first music-hall artist to perform at royal command. In the Cambridge Guide to Theatre, Nash is described as "a specialist in silly walks" and in the Oxford Companion to Popular Music as one who "pioneered the laughing song" (Gammond 1991, 415-16; Banham 1995, 777-78). Nash liked to refer to himself as "Jolly John Nash," and to prove he deserved the nickname, he composed and published a song in the 1890s titled "I'm such a jolly Man." Nash's selection of the Polytechnic as an appropriate topic for a music-hall song is indicative of its popularity in the $1860 \mathrm{~s}$. Nash assumes that everyone will get the jokes, and they depend on a widespread knowledge of the Polytechnic.

One final point about Pepper, which links him to the other science popularizers we have looked at who were not practitioners. Pepper's attitude towards scientific naturalism was somewhat complicated. Like Huxley and his allies he rejected spiritualism - indeed, he used his ghost illusion to dismiss spiritualism. But at some point in his life Pepper converted to Roman Catholicism, a decision normally fraught with serious consequences in Protestant England and usually an indication of strong religious convictions. According to one contemporary, Pepper was a sincere Christian who "never let slip an opportunity of impressing upon his hearers that the man of science by endeavoring to penetrate deeply into the hidden secrets of nature was guilty of no irreverence, and that the idea that science and unbelief go hand in hand was totally devoid of foundation." Pepper ended his astronomical lectures with arms and eyes raised, and with a quotation from the Psalms "The Heavens declare the Glory of God, and the firmament showeth His handiwork" (Boase 1965, 386; Wilkie n.d., 74). Pepper's conception of science as framed by religious themes is less obvious in his work than in Brewer, Gatty, or Wood's, but it is there.

\section{Conclusions}

One of the hallmarks of science from about 1830 was the proliferation of its sites. More and more science periodicals began to appear, accompanied by a huge explosion of books, museums, exhibitions, 
and lectures. In older stories about the formation of the worship of science from about 1850 to 1890 , historians tended to credit elite scientists such as Darwin or Huxley for the tenacious hold that science seemed to have on the hearts and minds of Victorians. But as scientific naturalists began to cultivate the strategy of professionalization, it committed them to privileging select spaces in which to practice legitimate science, such as the laboratory above all else. They were also selective about the sites in which they would communicate the results of their research and their views on the broader implications of scientific discoveries, whether it be in the Nineteenth Century, Nature, or other respectable periodicals, in elite scientific institutions such as the Royal Institution or the annual meeting of the British Association for the Advancement of Science, or on carefully organized lecture tours abroad. By pursuing professionalization as a route to reforming science, scientific naturalists left huge cultural spaces open to popularizers such as Brewer, Gatty, Wood, and Pepper. It was their religiously tinged agenda that members of the Victorian public encountered when they came into contact with science, just as much as the agenda of scientific naturalism.

I have tried to show how the roots of the cult of science of the second half of the nineteenth century can be traced back to earlier in the century, when the communications revolution took place and when there was an explosion of mechanics institutes in Britain. My account emphasizes the connections between the publication of cheap science books, the proliferation of scientific lectures, and the rise of scientific museums and exhibitions. These connections are embodied in the activities of some of the popularizers that were examined. Wood was both a scientific author and a lecturer. Pepper wrote science books, lectured extensively in Britain and elsewhere, and ran the Royal Polytechnic Institution. No doubt the details of the Canadian story differ from the British one. But the larger contours of the story must be similar, if only because what happened in Britain in the nineteenth century had a tremendous impact on developments in Canada and its founding provinces. Chambers' Vestiges of the Natural History of Creation caused a sensation in Canada, just as it did in Britain. Canadians read Gatty and Brewer. Scientific lecturers like Wood spoke about science to appreciative Canadian audiences. Though Canada as a young country did not experience a growth of science museums in the nineteenth century on the same scale as 
Britain, scientific societies in the provinces flourished. As we celebrate the $150^{\text {th }}$ anniversary of the establishment of the NSIS, we should recall its crucial connection to the many modes in which science was popularized in the nineteenth century in its mother country.

\section{REFERENCES}

Archives of George Routledge and Co., 1853-1902. 1973. Part I of British Publishers' Archives on Microfilm. Bishops Stortford: Chadwyck-Healey. Banham, M. 1995. The Cambridge Guide to Theatre. Cambridge: Cambridge University Press.

Boase, F. 1965. "Pepper, John Henry." In Modern English Biography, Volume I, L to Z, Supplement to Volume III, 386-87. London: Frank Cass.

Brewer, E. 1874. A Guide to the Scientific Knowledge of Things Familiar. London: Jarrold and Sons.

Brock, W.H. 2004. "Pepper, John Henry." In Lightman, B. (ed.), Dictionary of Nineteenth-Century British Scientists, 4 vols. Bristol: Thoemmes Continuum, 3: 1572-73.

Cambridge University Library, Royal Literary Fund, File no. 1982. John George Wood.

Cane, R.F. 1974-75. "John H. Pepper-Analyst and Rainmaker.” Journal of the Royal Historical Society of Queensland 9: 116-28.

Desmond, A. 1997. Huxley: From Devil's Disciple to Evolution's High Priest. Reading, M.A: Addison-Wesley.

Gammond, P. 1991. The Oxford Companion to Popular Music. Oxford: Oxford University Press.

Imperial College, London, Huxley Papers.

"Lectures for Altrincham and Bowdon." 1881. Altrincham and Bowdon Guardian, October 8: 5.

Lightman, B. 2007a. Victorian Popularizers of Science: Designing Nature for New Audiences. Chicago and London: University of Chicago Press.

Lightman, B. 2007b. "Lecturing in the Spatial Economy of Science." Science in the Marketplace: Nineteenth-Century Sites and Experiences, Ed. Aileen Fyfe and Bernard Lightman, 97-132. Chicago and London: University of Chicago Press.

McMillan, N.D., and Meehan, J. 1980. John Tyndall: 'X'emplar of Scientific and Technological Education. Dublin: ETA Publications.

Nash, J. [1860]. Laughing Gas or A Night at the Polytechnic. London: Weippert \& Co.

"Rev. J.G. Wood.” 1890. Saturday Review 69: 479.

“Royal Polytechnic.” 1866. Illustrated London News 48 (May 26): 511.

Rupke, R. 1994. Richard Owen: Victorian Naturalist. New Haven, CT: Yale University Press. 
Secord, J. 2000. Victorian Sensation: The Extraordinary Publication, Reception, and Secret Authorship of Vestiges of the Natural History of Creation. Chicago and London: University of Chicago Press.

Secord, J. 2002. "Quick and Magical Shaper of Science." Science 297 (September 6): 1648-49.

Shapin, S., and Barnes, B. 1977. "Science, Nature and Control: Interpreting Mechanics' Institutes." Social Studies of Science 7: 31-74.

St. Clair, William. 2004. The Reading Nation in the Romantic Period. Cambridge: Cambridge University Press.

University of Westminster Archives, Press Cuttings, Book of Press Cuttings Relating to RPI, 1863 [January 4], "Polytechnic Institution."

Vincent, David. 1989. Literacy and Popular Culture: England 1750-1914. Cambridge: Cambridge University Press.

Whitehead, A. 1889. “The Late Rev. J. G. Wood.” Times, March 9: 15.

Wilkie, E.H. n.d. "Professor Pepper-A Memoir." The Optical Magic Lantern Journal and Photographic Enlarger, 72-74, from the University of Westminster, Archive, R66/4i-iii.

Wood, J. 1872. Insects at Home: Being a Popular Account of British Insects, Their Structure, Habits, and Transformations. London: Longmans, Green.

Wood, J. 1883. Insects Abroad: Being a Popular Account of Foreign Insects, Their Structure, Habits, and Transformations. London: Longmans, Green.

Wood, R. 1890. The Rev.J. G. Wood: His Life and Work. New York: Cassell Publishing Company. 
